\title{
VAMPIRIC AFFINITIES: MINA HARKER AND THE PARADOX OF FEMININITY IN BRAM STOKER'S DRACULA
}

\author{
By Charles E. Prescott and Grace A. Giorgio
}

\begin{abstract}
AFTER MINA HARKER awakens from Count Dracula's vampiric embrace, she asks the men around her, but more pointedly herself, "What have I done to deserve such a fate, I who have tried to walk in meekness and righteousness all my days?" (285, ch. 21$)$. As she recounts this perverse seduction in her own words, however, she contradicts her earlier disavowal: "strangely enough, I did not want to hinder him" (284). These conflicting statements capture the peculiar double bind with which Mina struggles throughout Bram Stoker's Dracula (1897). Many critics concentrate on Dracula himself and the men who do battle with him; interestingly, the novel also develops Mina's complex subjectivity through her unspoken but deep affinity with the vampire. Van Helsing's paranoid observation, "Madam Mina, our poor, dear Madam Mina, is changing" (319; ch. 24), epitomizes shifting cultural anxieties at the moment when a long-standing ideological conception of proper femininity ${ }^{1}$ comes under suspicious attack. Although nothing seems more natural to Mina than her desire to help her husband in the public sphere while maintaining an intimate friendship with Lucy Westenra in the private, these familiar roles become estranged by the new taxonomies of deviancy popularized during the late nineteenth century.

Mina Harker exists on the cusp of culturally overdetermined boundaries that were undergoing extensive revision during the Victorian fin de siècle. As David Glover has argued, Stoker's text reveals "a fixation with unfixing the boundaries, with the attractions of liminality, in order that the lines of demarcation might be all the more strictly controlled" (48). By exploring these borders and their effects, Stoker attempts to shore up the seemingly besieged categories of Englishness, manliness, and national identity. Just as Stoker's other Gothic disruptions flirt with and transgress boundaries of personal identity, his portrayal of Mina Harker as "a stereotypically 'good' little Victorian Miss" (Sally Ledger's term, "The New Woman" 30) troubles any simple definition of normative femininity. Although Mina would like to understand herself as the ideal Victorian woman described by Van Helsing, her affinity with the vampire becomes legible through her ambivalence about the "New Woman," her passionate friendship with Lucy, and the uncanny moments when her gender performance comes into question. Following the methods of sexologists who place such friendships under suspicion, Van Helsing subjects both Mina and Lucy to an interpretive, disciplinary gaze, looking for bodily stigmata of degeneracy as well as tell-tale transgression in their letters.
\end{abstract}


Lucy's descent into vampirism as well as Mina's desperate attempts to disavow her own vampiric affinities reveal not only the coercive power of Victorian femininity but also the possibility of a cultural space in which to perform a radically different female agency that neither patriarch - Van Helsing nor Dracula - can ultimately control.

\section{“The Least Beautiful Thing”: Mina Harker and the New Woman Question}

ALTHOUGH MINA MURRAY HARKER plays an integral role throughout the adventure of identifying, tracking, and then destroying the vampire, several critics interpret her as completely passive. For instance, Sally Ledger presents Mina as "a woman who, firmly rooted in the maternal paradigm, settles for the 'ideal' of middle-class Victorian womanhood" (New Woman 105). By remodeling herself into a "modernised version of the 'angel in the house," Mina "inscrib[es] herself within the paradigm of ideal Victorian womanhood by acting as a moral guardian of society" (106). ${ }^{2}$ In contrast, David Glover regards Mina as "extremely hard to place," both "an unmoored sign of change as well as a firm attempt to hold the line against the New Woman" (96-97). Because her own self-representation is often annoyingly self-effacing, it is not surprising that Mina's multifaceted agency is frequently downplayed in the criticism of the novel. She frequently casts herself as the assistant schoolmistress of etiquette, the devoted helpmate of Jonathan Harker, and the compassionate, maternal shoulder that "manly" men turn to when overcome by emotion. In fact, Mina likes to present herself as Van Helsing describes her, as one of the "good women still left to make life happy - good women, whose lives and whose truths may make good lesson for the children that are to be" (182; ch. 14). Yet if we resist this self-presentation and place Mina squarely within two late-century discourses of disputed femininity, the New Woman and passionate friendship, a much more ambivalent sense of self becomes legible.

Rejecting the home and traditional motherhood as the only acceptable occupation for women, the New Woman actively sought educational fulfillment and work where none had existed before, in medicine, nursing, education, and the newly forming Typing Girl pools. ${ }^{3}$ This mass entry into the public sphere alarmed many, both men and women. As Ledger documents, the dominant discourse of New Womanhood was a reaction of the popular press against the advances won by bourgeois feminists. To the conservative journalist and novelist Ouida, the New Woman is a humorless, unwomanly bore who threatens civilization with "her fierce vanity, her undigested knowledge, her over-weening estimate of her own value and her fatal want of all sense of the ridiculous" (615). In an 1895 Blackwood's article titled “Tommyrotics," Hugh E. M. Stutfield presents the New Woman as senselessly overeducated and ridiculous: "With her head full of all the "ologies and "isms, with sex-problems and heredity, and other gleanings from the surgery and the lecture-room, there is no space left for humour, and her novels are for the most part merely pamphlets, sermons, or treatises in disguise" (837). Describing these works as "physiologico-pornographic" (836), Stutfield's article is typical of discussions of sexual knowledge and freedom that earned New Woman writers the title of "erotomaniacs." Popularizers of eugenics like Henry Maudsley and Charles Harper argued that overeducated women threatened the well-being of the British Empire: according to Harper, "nature, which never contemplated the production of a learned or a muscular woman, will be revenged upon her offspring, and the New Woman, if a mother at all, will be the mother of a New Man, as different, indeed, from the present race as 
possible, but how different, the clamorous females of today cannot expect" (qtd. in Ledger, New Woman 18). Summing up all these cultural anxieties of the fin de siècle, Mrs. Roy Devereux writes, "Life has taken on a strange unloveliness ... and the least beautiful thing therein is the New Woman" (qtd. in Cunningham 1).

Contrary to the monolithic image created by the conservative press, late-century feminists and New Woman authors themselves differed widely on their views of who the New Woman was and what she stood for, especially on questions of sex. The New Woman novelist Sarah Grand would respond to charges of "erotomania" that it was men, not women, who are a threat to the race:

The [Bawling Brotherhood] consists of two sorts of men. First of all is he who is satisfied with the cow-kind of woman as being most convenient; it is the threat of any strike among his domestic cattle for more consideration that irritates him into loud and angry protests. The other sort of Bawling Brother is he who is under the influence of the scum of our sex, who knows nothing better than women of that class in and out of society, preys upon them or ruins himself for them, takes his whole tone from them, and judges us all by them. Both the cow-woman and the scum-woman are well within range of the comprehension of the Bawling Brotherhood, but the new woman is a little above him.... (270-71)

Preferring prostitutes and loose women on the one hand and mindless, bovine, child-bearing machines on the other, the men Grand describes do not have the moral character of the "new woman," who only desires sexual knowledge and employment opportunities as a way of avoiding venereal disease and complete dependence on men. Influenced by public debates on the Contagious Diseases Acts, Grand wrote her novel The Heavenly Twins to protest that "nothing has yet been done to protect the married woman from contagion" by diseases such as syphilis (qtd. in Ledger, New Woman 113). ${ }^{4}$ Other New Woman writers, including George Egerton and Grant Allen, did explore women's eroticism and made more radical demands about sexual freedom. Still, other female activists distanced themselves from Allen in particular; as Teresa Mangum notes, female suffragist Millicent Garrett Fawcett largely rejected any connection to the New Woman of the popular press, claiming that "Mr. Grant Allen has never given help by tongue or pen to any practical effort to improve the legal or social status of women. He is not a friend but an enemy" (Married 28-29). In this highly charged, ongoing discursive battle, the New Woman presented a problem that demanded extensive cultural discussion, argument, and rethinking: "All that was certain was that she was dangerous, a threat to the status quo" (Ledger, New Woman 11).

The difficulty of interpreting Mina's relation to traditional femininity and the New Woman is firmly in place well before we read any of her own writings, for throughout his Transylvanian travel log Jonathan Harker has constructed his fiancée as he imagines her. Rambling through the forbidden sections of Castle Dracula, Harker indulges in a wish fulfillment of his own chivalric ideal, imagining "some fair lady" who "with much thought and many blushes" writes "her ill-spelt love letter"; "I determined not to return to-night to the gloom-haunted rooms, but to sleep here, where of old ladies had sat and sung and lived sweet lives whilst their gentle breasts were sad for their menfolk away in the midst of remorseless wars" (35-36; ch. 3). Of course Harker's languorous fantasy of passive femininity soon gives way to the all-too-active vampiric titillation of the three sisters of Castle Dracula, recasting Harker himself as an unmanly, passive threat to Victorian gender 
norms. ${ }^{5}$ But even in the midst of this dreamy seduction his thoughts turn to Mina: "It is not good to note this down, lest some day it should meet Mina's eyes and cause her pain; but it is the truth" (37). Perhaps most crucially to Harker as he battles to free himself from Castle Dracula and maintain some measure of his masculine identity, the idealized Mina serves as a stark contrast to the actively sexual vampiric women: "I am alone in the castle with those awful women. Faugh! Mina is a woman, and there is naught in common. They are devils of the Pit!" (52; ch. 4). By making these women's monstrosity contingent on Mina's purity, Harker naturalizes her propriety as the limit of the imaginable. Harker's rather desperate reading of Mina's unquestionable purity largely parallels Van Helsing's later in the text without a clearly defined, passive femininity against which to define himself and his world, Jonathan Harker crumbles into a nightmare of uncertainty, confusion, and vampiric "brain fever."

The initial image we form of Mina through her exchange of letters with Lucy, however, begins to challenge Harker's chivalric ideal. Mina tells her "dearest Lucy" that "I have been simply overwhelmed with work. The life of an assistant schoolmistress is sometimes trying." Along with this job, Mina also mentions her other work activities: learning shorthand, keeping a journal, and doing "what I see lady journalists do." Mina justifies her eagerness to work as a desire to help her future husband: "I have been working very hard lately, because I want to keep up with Jonathan's studies" (53; ch. 5). This proper self-presentation leads Salli Kline to read Mina's skills as merely "up-to-date housekeeping" (135) to help her up-to-date husband, yet we can wonder how a lady journalist could possibly help a solicitor's clerk. ${ }^{6}$ Mina considers her journal not only a way to help Harker but also an ascetic regimen of self-improvement: "I don't mean one of those two-pages-to-the-weekwith-Sunday-squeezed-in-a-corner diaries, but a sort of journal which I can write in whenever I feel inclined. ... [I]t is really an exercise-book" (53; ch. 5). While on vacation in Whitby with Lucy, Mina retires to the picturesque local cemetery in order to work: "I shall come and sit here very often myself and work. Indeed, I am writing now" (62; ch. 6). Here her topic is one Mr. Swales, a hundred-year-old local who tells stories to Mina and Lucy in very broad dialect which Mina meticulously reconstructs. The loquacious Mr. Swales sets the scene of Dracula's entry into England via a storm-driven ghost-ship, but more importantly his presence highlights the journalistic mixture of texts and voices, recreated by none other than lady journalist Mina. ${ }^{7}$ Whether Mina has more in common with the conservative journalist Ouida or the progressive Sarah Grand, who between them christened the "New Woman" (Jordan 19-21), can be debated, but Mina's commitment to work positions her as something other than Jonathan Harker's passive, chivalric ideal. Despite her disclaimers of wifely propriety, writing represents for Mina an attempt to establish a strong sense of self, which in this charged historical moment carries the political resonance of the New Woman.

Mina clearly demonstrates her awareness of the New Woman debate, referring to the New Woman directly twice in her journal entry dated August $10 .^{8}$ In an attempt to help the hypersensitive Lucy overcome her sleepwalking, Mina takes her on a long walk, stopping for a "severe tea" along the way: "I believe we should have shocked the 'New Woman' with our appetites. Men are more tolerant, bless them!" Although Mina moves to consolidate her bit of "New Woman" wit by blessing tolerant men, her next invocation of the New Woman reveals more ambivalence. As she gazes on a sleeping Lucy who "looks, oh, so sweet," she thinks about Lucy's new fiancé: "If Mr Holmwood fell in love with her seeing her only in 
the drawing-room, I wonder what he would say if he saw her now" (88; ch. 8). Again her thoughts turn to the New Woman:

Some of the "New Woman" writers will some day start an idea that men and women should be allowed to see each other asleep before proposing or accepting. But I suppose the New Woman won't condescend in future to accept; she will do the proposing herself. And a nice job she will make of it, too! There's some consolation in that. (88-89)

Mina tries to strike a derisive tone here, and most critics take her at her word. Yet if Mina, like the conservative press, sees these women as simply "erotomaniacs" who are obsessed with improper sexual freedom, then what consolation would she take in their proposal? Despite her apparent tone, she cannot distance herself from the sentiments the New Woman represents, particularly if we think of a writer like Sarah Grand. For Grand the New Woman herself might do the proposing, not because of rampant sexual appetite but to insure that the man she selects is up to her moral standard. While Grand's "exposé of the underbelly of male sexuality" (Ledger, New Woman 114) drew many attacks on her as an erotomaniac, perhaps even by Stoker himself, Mina's thoughtful reverie on female proposal takes on another valence of meaning in a cultural climate and in a text that puts such importance on issues of knowledge, sexual and otherwise. ${ }^{9}$

In a novel obsessed with the importance of careful note-taking and accurate recording, Mina is the key to the text, for it is Mina's task to "create the knowledge by which Dracula is destroyed" (Brennan 4). There is only one exception to Mina's commitment to careful journalism, and it comes at a time when her commitment to traditional wifely femininity is heavily overdetermined. Having just learned that Harker is in a hospital in Budapest, Mina rushes to his side. Mina's eyes light up when she sees his notebook, hoping it will explain his strange disappearance and illness, but Harker (who supposedly remembers nothing of his ordeal) decides he must swear her to wifely ignorance:

\footnotetext{
"Wilhelmina ... you know, dear, my ideas of the trust between husband and wife: there should be no secret, no concealment. I have had a great shock, and when I try to think of what it is I feel my head spin round, and I do not know if it was all real or the dreaming of a madman. You know I have had brain fever, and that is to be mad. The secret is here, and I do not want to know it. ... Are you willing, Wilhelmina, to share my ignorance? Here is the book. Take it, and keep it, read it if you will, but never let me know." (103; ch. 9)
}

Mina not only agrees to share Harker's ignorance but, as Talia Schaffer describes, turns her ignorance into a fetish object of their relationship. In a letter to Lucy, Mina describes how she "took the book from under his pillow, and wrapped it up in white paper, and tied it with a little bit of pale blue ribbon which was wound round my neck, and sealed it over the knot with sealing-wax, and for my seal I used my wedding ring. Then I kissed it and showed it to my husband, and told him that I would keep it so, and then it would be an outward and visible sign for us all our lives that we trusted each other" (104). Where Schaffer reads the journal in terms of its homoeroticism, ${ }^{10}$ we can also read it in the terms Harker mentions specifically: the seduction of the vampiric women. Although Mina denies she was even potentially worried that Harker had been with another woman, the nuns put her mind at ease and she confesses satisfaction when she "knew that no other woman was a cause of trouble" (103). If we borrow Grand's terms, we might say that Mina is glad Jonathan has 
not been cavorting with any "scum-women." In the context of the Contagious Disease Acts and Grand's novels, Mina has accepted the chivalric ignorance of the virtuous wife, the "cow-woman" of Grand's provocative formulation, disavowing even the desire for knowledge, even if that knowledge could infect her with a dangerously foreign disease, be it syphilis or vampirism.

Despite her wifely devotion, however, Mina tears open the journal and reads it at the first hint of trouble, when Harker sees Dracula in Piccadilly. Not only does she tear up her fetish of ignorance, she soon types it in triplicate to circulate this knowledge as widely as possible. She does indeed read the story of her husband's vampiric seduction and, as Jennifer Wicke playfully points out, may even have authored its more lurid moments, for Mina is translating from Harker's shorthand, and "What, after all, is the stenographic version of 'kiss me with those red lips'[?]" (Wicke 471). True to his earlier prediction, Harker's bit of vampiric titillation and gender-bending passivity in Castle Dracula does indeed cause Mina pain when she reads it. Yet Mina turns her pain into a kind of purity crusade typical of late-Victorian feminists; she makes sure her wayward husband's transgressions become a site of public discourse, and that his story will form a crucial kind of knowledge to protect the ignorant in the future.

Mina's relationship to knowledge marks her as a problem according to Van Helsing's model of taxonomy and his falsely idealizing way of describing her: "Ah, that wonderful Madam Mina! She has man's brain - a brain that a man should have were he much gifted and woman's heart" (232; ch. 18). While Van Helsing offers up his fulsome praise to stroke Mina's sense of propriety, his broken English reflects the gender-based problem she poses within the text - in this cultural milieu of sexology, the "third sex," and the Woman Question, Mina cannot cross gendered boundaries with impunity. Whether she purports to be proper or not, she must be forced back into her role of proper, submissive femininity. Tellingly, Van Helsing offers his praise just before he cuts her out of the "little band of men" (373; ch. 27) as they fight the vampire. Though she has sutured together the journals, all the men (including Jonathan) agree that, in Seward's words, "Mrs Harker is better out of it" (253; ch. 19). Yet, as we shall see, this exclusion from knowledge, work, and activity provokes the "devouring anxiety" (254) that draws the vampire to her. Mina's relationship to the New Woman and knowledge indeed makes her an "unmoored sign of change" (Glover 96), whether she wants to be or not.

\section{Reading the Rave: The Cultural Politics of Passionate Friendship}

IF STOKER'S PORTRAYAL of Mina's idealized purity takes on unexpected valences of meaning through Van Helsing's image of her man's brain and woman's heart, another seemingly straightforward character trait also becomes problematic in the cultural context of the Victorian fin de siècle - Mina's powerful friendship with Lucy. As we might expect, the men praise Mina and Lucy for their deep friendship, reading it as proof of their mutually exemplary characters. On the surface, such a strong friendship is simply proof of "the seriousness of one's moral character" (Faderman 151), as it had been during an 1811 libel case against two schoolmistresses suspected of a sexual relationship: "A woman who is not capable of the tenderest feelings and deepest intimacy toward her friend is lacking in an essential human component" (Faderman 153). ${ }^{11}$ In the cultural climate of feminist reform, sexology, and degeneration anxiety, however, the essential inviolability and asexuality of 
female friendship comes under suspicious attack: "the New Woman as she was constructed in the periodical press of the 1890s rapidly distinguished herself as a lesbian prototype" (Ledger, New Woman 124). While lesbian relationships are more often read in Dracula's predecessor, Joseph Sheridan Le Fanu's "Carmilla" (1872), ${ }^{12}$ the passionate friendship of Mina and Lucy can be read through their intimate letters and journals as a transitional moment in the collective understanding of female friendships. Though Mina herself would most likely read her friendship as completely natural and innocent, in the ideologically charged climate of vampirism and gender slippage it too takes on an uncanny social significance.

Female friendships and their intimacy register as either benign or threatening, depending on specific cultural anxieties. Lillian Faderman demonstrates that during the eighteenth and early nineteenth century, European women enjoyed tolerance for their intimate friendships due to cultural denial that women experienced sexual desire: "the sexual potential of love between decent, healthy women was still unacknowledged by many seemingly sophisticated authors: sound women were asexual" (156). ${ }^{13}$ Paradoxically, however, such social denial gave range to a certain class of women to explore their intimate friendships with little threat of outside scrutiny: "for a brief period at the end of the last century, social innocence - or denial about female sexuality, combined with increased economic opportunities and independence, permitted a generation of middle- and upper-class women to make intimate same-sex relationships the emotional, if not the erotic, center of their lives" (Miller 63). Offering an extensive list of same-sex relationships between such women as Eleanor Marx and Olive Schreiner, Edith Simcox and George Eliot, and Geraldine Jewsbury and Jane Welsh Carlyle among others, Sally Ledger concludes that "Although few of the specific relations ... between women ... were self-consciously lesbian, they were undoubtedly intimate, and it seems likely that same-sex love between Victorian women was not, as Margaret Fuller would have it, always 'purely intellectual and spiritual"' (New Woman 127).

Nevertheless, such tolerance was short lived as feminist advances in work and education began to disrupt the gendered binaries of public and private, domestic and professional. No longer forced to marry for survival and social status, women could exist without men and without marriage; as Sheila Jeffreys notes, "Emotional relationships between women were harmless only when women had no chance to be independent of men, and became dangerous when the possibility of women avoiding heterosexuality became a reality" (20). Discussing the nineteenth-century American context, Nancy Sahli sums up this new situation:

\footnotetext{
As long as women loved each other as they did for much of the nineteenth century, without threatening the system itself, their relationships either were simply ignored by men or were regarded as an acceptable part of the female sphere. Feminists, college graduates, and other independent women, however, were a real threat to the established order, and one way to control these sexless termites, hermaphroditic spinsters, or whatever one might call them, was to condemn their love relationships - the one aspect of their behavior which, regardless of their other social, political, or economic activities, posed a basic threat to a system where the fundamental expression of power was that of one sex over another. (27)
}

What for decades had been considered normal, benign, even a sign of "true womanhood" was now rendered pathological in the wake of the New Woman and the challenge she posed. In the interest of pathologizing in order to render normative, the category of "lesbian identity" had to be created in order for it to be threatening. 
Reacting against this perceived threat, conservative writers in the periodical press linked together two disparate figures, the New Woman and the dandy, as potential disruptors of the status quo. All who deviated from gendered norms received vitriolic charges of breaking essential gender codes. Eliza Lynn Linton attacked male supporters of the "Wild Women" as being just as unmasculine as these women are unfeminine: "The less lovely the thing, the more ardently it is celebrated by the men whose main endeavor in this direction is to destroy the old ideals, and to substitute for the beautiful woman of history and fiction the swaggering Wild Women of the present craze. The truth is simply this - the unsexed woman pleases the unsexed man" (461). While female suffragists and decadent writers like Oscar Wilde did not necessarily see themselves as allies, and in fact attacked each other in the press, ${ }^{14}$ the popular press grouped them together in an attempt to contain and parody their potentially similar disruptions of essentializing gender norms. As Martha Vicinus notes, such labeling could have a strong political effect: "When women appeared to be stepping outside their preconceived social role, they were pigeonholed as sexually variant, a label that was easy for journalists to use during periods of feminist militancy" (62).

Another potent political voice offering explanations for these disruptions came from the scientific community. A new medical model, the sexology of Karl Westphal, Richard von Krafft-Ebing, and Havelock Ellis, like Cesare Lombroso's criminal anthropology, read the signs of degeneracy in "the deviations found in the general conformation of the body" (Ellis 289). ${ }^{15}$ As George Chauncey explains, the Victorian gender/sex sign system defined "sound" women as completely feminine and "sound" men as masculine; "sexual inversion" focused less on an object of desire and more on a perceived inversion of one's social and gender role. To locate the signs of deviance, Ellis identified male inverts through their physical and behavioral signs: "there is a distinctly general, though not universal, tendency for sexual inverts to approach the feminine type, either in psychic disposition or physical constitution, or both" (287). More problematic, however, was the fact that women's bodies frustrated this type of reading strategy. Ellis observes that, "we are accustomed to a much greater familiarity and intimacy between women than men, and we are less apt to suspect the existence of any abnormal passion" (204). He also notes the ambiguous nature of these intimate alliances: "conventional propriety recognizes a considerable degree of physical intimacy between girls, thus at once encouraging and cloaking the manifestations of homosexuality" (218). Even more perplexing, if a woman felt a high degree of sexual attraction for another woman, she lacked the language and social understanding to realize her affection was sexual (204). ${ }^{16}$ As Chauncey describes this social and sexual conundrum, "in the context of female passionlessness, there was no place for lesbianism as it was currently understood: if women could not respond with sexual enthusiasm to the advances of men, how could they possibly stimulate sexual excitement for each other?" (118).

Nevertheless, sexologists sought to identify sexual inversion in women, downplaying the sexual potential of women's intimate friendships and foregrounding these women's physical appearance and social behavior. Dividing congenitally inverted women from the "perverts" those who could be swayed one direction or the other - Ellis found a "more or less distinct trace of masculinity" (222) in congenitally inverted women. The more reactionary KrafftEbing directly linked "lesbianism to the rejection of traditional female social roles, to crossdressing and to 'masculine' psychological traits" (Ledger, New Woman 129). Under the careful and politically invested eye of the sexologist, any unfeminine behavior, or even behavior that had long been viewed as completely acceptable, could now be classified as 
pathological. By the early twentieth century, female friendships transitioned from being tolerated, even encouraged, to medicalized as sick.

Regarded as "a vice of modern refined civilization" (Ellis 204), female homosexuality was especially fostered in those sites which kept women in constant association. While Ellis refrained from claiming that feminism caused lesbianism, he does associate sites of feminist activity like women's colleges and political clubs with a higher rate of sexual inversion: "I do not say that these unquestionable influences of modern movements can directly cause sexual inversion, though they may indirectly, in so far as they promote hereditary neurosis; but they develop the germs of it" (qtd. in Ledger, New Woman 130). The expansion of educational opportunities for young girls and women in the latter half of the nineteenth century provided new arenas in which women and young girls could come together for a common purpose outside of traditional home-life. As Neil Miller notes, "One aspect of the women's college experience that clearly had an impact on the prevalence of these relationships was 'smashing,' the romantic crushes, presumably nonsexual (but perhaps not?), that flourished in closed same-sex environments" (60). Stumped by the lack of overt bodily signs of deviant sexuality on the female body, sexologists sought data for their assertions in all-girl schools, interviewing ex-schoolgirls and reading their letters to expose aberrant tendencies.

According to Ellis's informants (former schoolgirls who often were themselves once "gone on" a female friend), hardly anyone was free from a "rave," another term for these romantic friendships: "Any fresh student would soon fall a victim to the fashion, which rather points to the fact that it is infectious. Sometimes there might be a lull in the general raving, only to reappear after an interval in more or less of an epidemic form" (377). Usually between an older girl and a younger one, but sometimes affecting teachers as well, raves allowed these girls and women to experience a kind of sexuality outside of a heterosexual space:

In the case of two girls there is more likely to be a sexual element, great pleasure being taken in close contact with one another and frequent kissing and hugging. When parted, long letters are written, often daily; they are full of affectionate expressions of love, etc.... Their various emotional feelings are described in every minute detail to each other. (Ellis 378-79)

Occasionally, Ellis's informant notes, the duration of raves extended beyond schoolgirl life despite the girls' introduction to male society: "These friendships are often found among girls who have left school and have every liberty, even among girls who have had numerous flirtations with the opposite sex, who cannot be accused of inversion, and who have all the feminine and domestic characteristics" (379). Ellis notes several raves lasting well into later life, holding out the potential for a life outside of the Victorian norm.

Set in this overdetermined cultural moment, the friendship between Mina and Lucy serves as a site of suspicious redefinition. Stoker's novel of identification and recuperation subjects the writing of Lucy and Mina as well as their bodies to a rigorous interpretive gaze. Nancy Sahli describes "the fall" (when passionate friendship came under attack) by reading intimate letters passed between female friends. She addresses the problem of language these women did not have the same terminology we have today - yet finds "a high degree of emotional, sensual, and even sexual content" (18) in their relationships through their expressive letters. She notes that whereas letters from the 1860 s and 70 s were sometimes 
overtly passionate, "After the early 1870's, however, this type of letter becomes increasingly scarce, and those that do exist convey the impression of being rhetorically self-conscious rather than innocently emotional in their language" (19). We find this level of self-conscious intimacy in Mina and Lucy's letters. The only true intimate writing exchanged in the novel, these letters mark Lucy as an effusive, silly schoolgirl and sexually excessive New Woman. However, in light of the self-conscious veiling used by female friends, Lucy's theatrical avowals of her pleasure of being engaged to Arthur Holmwood - "I love him, I love him, I love him!" (55; ch. 5) - ring oddly flat when she relegates him to a second postscript: “Oh, about number three - I needn't tell you of number three, need I?" (59). Lucy is not indiscriminately sexual; she shows remarkably little interest in or passion for the man her mother has chosen to be her husband. ${ }^{17}$ She is much more affected by Quincey Morris, whom she kisses, and the vampirically seductive Count, who kisses her. Lucy's most effusive moments of pleasure, however, are not directed at any of her male suitors. Whether thanking Mina for her "sweet letter" (55) or sending her "Oceans of love and millions of kisses" (105; ch. 9), Lucy's most passionate connection is undoubtedly with her dear friend. When she writes, "I wish I were with you, dear, sitting by the fire undressing, as we used to sit" (55; ch. 5), she captures the intimacy of the rave relationship. Ellis describes one rave relating how her friend "liked to see me with my hair down and would rest her head on my shoulder, especially if I were partially undressed" (372). ${ }^{18}$ Despite this homoerotic charge, Lucy and Mina remain unself-conscious about the nature of their friendship, valuing their intimacy not as sexual but as an idealized connection.

Mina responds to Lucy's affectionate letters with a more muted tone. Unlike Lucy's "Oceans of love," Mina's letters and journals are a chance to work, to practice with ascetic self-discipline the skills of the lady journalist. However, Mina's reticence suggests her own coded participation in this rave. While Mina and Lucy seem to have been friends since childhood, Mina acts as mentor and teacher to Lucy as well as to her students at her etiquette school. As Ellis notes, teachers and older students often became the beloved object of a rave, playing a restrained but still erotically charged role in the relationship. Martha Vicinus suggests that due to the public surroundings of the school, those involved in a rave developed symbolic communication techniques to express their affection: "The secret sharing of a private world in a public place became a major source of pleasure; it affirmed the love, while never removing it from the realm of self-discipline" (51). Mina's letters and journals reflect a code of intimate expression, based on "symbolic acts and symbolic conversations" (50). In her first letter to Lucy, Mina expresses her desire to be with her friend symbolically: "I am longing to be with you, and by the sea, where we can walk together freely and build our castles in the air" (53; ch. 5). This ethereal imagery creates a safe imaginary space that displaces the homoerotic potential of this intimacy. Marriage and heterosexuality itself could become an eroticized topic of intimate communication. As Ellis's source recalls her experiences, she reveals that discussions about sex were rampant among the schoolgirls: "The majority of the girls are entirely ignorant of all sexual matters, and understand nothing whatever about them. But they do wonder about them and talk about them constantly, more especially when they have a 'rave,' which seems to point to some subtle connection between the two" (378). For Mina and Lucy as well, marriage and heterosexuality become a frequent topic of conversation; whether holding hands in Whitby cemetery $(67 ;$ ch. 6) or cuddling in bed and discussing what happens after marriage $(92 ; \mathrm{ch} .8)$, the marriage trope becomes a powerful marker of intimacy between these passionate friends. Coded into propriety rather 
than pathologized as inversion, such desire could be sublimated into the most idealized form of female friendship.

Vicinus further argues that such sublimated desire through self-denial of physical intimacy was all the sweeter because it tied into the model of moral self-restraint. It is difficult to locate rave recipients' affections in letters and journals, since the older women "downplayed the emotions that they had fanned, sometimes using them to enhance their own self-image publicly and privately" (54). The rave relationship became an opportunity to express one's self-constraint as well as a chance to impart such lessons to the younger girl: "self-control became a key means of expressing love within the boarding-school world" (45). The older women could "break their silence through letters of advice, consolation and love" (55-56), a practice Mina exercises with her motherly advice. In a letter informing Lucy of her marriage to Harker, she presents herself as an object lesson of wifely duty:

\footnotetext{
Lucy dear, do you know why I tell you all this? It is not only because it is all sweet to me, but because you have been and are, very dear to me. It was my privilege to be your friend and guide when you came from the schoolroom to prepare for the world of life. I want you to see now, and with the eyes of a very happy wife, whither duty has led me; so that in your own married life you too may be all happy as I am. My dear, please Almighty God, your life may be all it promises: a long day of sunshine, with no harsh wind, no forgetting duty, no distrust. I must not wish you no pain, for that can never be; but I do hope you will be always as happy as I am now. (104; ch. 9)
}

This letter ostensibly presents the "pedantic, irritatingly didactic, know-it-all Mina" (Kline 133) at her most irritating and pedantic, "for you can't go on for some years teaching etiquette and decorum to other girls without the pedantry of it biting into yourself a bit" (168; ch. 13). Although presenting herself as a very proper woman here, Mina emphatically refers to the space of the rave. Taking on the voice of the motherly, experienced teacher, Mina instructs Lucy on exactly what good womanhood entails: marriage, duty, self-effacement, pain. However, even the terms of this propriety speak the possible transgressive potential of the rave - by invoking the schoolroom, Mina harks back to a connection that many women felt to be much more fulfilling than marriage. As she gives her dear friend these words of advice, consolation, and love, the act of giving advice itself takes on a different charge, continuing their relationship even as it poses as an ideal lesson in proper conduct. Mina's rigid self-restraint, sacrificing her friendship though still continuing to value it, functions as self-instruction, perfecting her character in the societal terms available to her.

Although seemingly unaware of the disruptive potential of their friendship, Mina and Lucy still deploy tactics that veil their impulses. Mina's and Lucy's letters and journals produce a series of narrative confessions presented as both normal and destabilizing. As Marjorie Howes points out, Lucy's seemingly inappropriate sexual desire is expressed in a series of retractions and corrections of her expression of heterosexual desire (104). These corrections, however, as Howes observes, also function as the suppression of homoerotic desire, as when Lucy claims, "I know now what I would do if I were a man and wanted to make a girl love me. No, I don't" (57; ch. 5). Imagining herself in the position of a man desiring a woman, Lucy catches her transgression and immediately retracts her statement. Mina also has such moments of correction, though more muted. In her initial letter to Lucy, Mina writes, "It must be so nice to see strange countries. I wonder if we - I mean Jonathan and I - shall ever see them together" (53-54). As slight as this ambiguity may seem, Mina, 
like Lucy, sees the need to correct her expression of desire, for "we" could mean Lucy and herself. This pattern of self-correction, seemingly banal enough, contributes to a homosocial community of shame in which to confess is simultaneously to hold oneself up to a normative standard, naturalizing that standard as normality. Through this judgment, "[b]y no longer making the confession a test, but rather a sign" (Foucault 67), the subject not only accepts the judgment as truth but also internalizes it as the socially validated code of conduct. ${ }^{19}$ Yet to speak that which should not be spoken, to acknowledge the potential for doing that which should not be done, also allows for possible resistance. The potential of the passionate female friendship, especially in the cultural climate of the New Woman, is that a woman could decide to live outside of standardized Victorian gender codes - not that she would, but that she might. The gendered doctrines of separate spheres - female domesticity and male superiority - begin to show strain under this potential disruption. Lucy's and Mina's moments of transgression, whether a simple slip of the tongue or a kiss from the vampire, move their friendship further from the tolerated space of the romantic friendship and closer to the sign of gender slippage that must be repulsed, the vampire.

\section{"A Certain Affinity to the Monstrous": Van Helsing, the Scapegoat, and the Cruel Art of Discipline}

CONTRASTING REALIST NEW WOMEN NOVELS with more melodramatic and more popular Gothic and sensation fiction of the nineteenth century, Teresa Mangum contends that by showing the minutia of everyday Victorian life and marriage, rather than focusing on the extraordinary fantasies of "[v]ictimized Gothic heroines, fallen women, and terrifyingly feminine murderesses" (Married 12), realist women writers sought to deal directly with the social and political issues of the day. Yet Gothic novels are not necessarily divorced from the political. David Glover highlights the strong connections between Stoker's political investments and his Gothic fantasies and adventure stories: "it is essential to see that the anxieties that animate these novels are inextricably bound up with the most deeply rooted dilemmas facing late Victorian culture" (15). Whereas Mina's relationship to work and her deep friendship with Lucy could very well be the focus of a realist New Woman novel, it is the deep affinity she feels with the Count, and the constant self-scrutiny demanded by Van Helsing, that makes this narrative of subject formation particularly Gothic. Count Dracula, much like Mary Shelley's creature, is the perfect monster because of the sheer number of anxieties collapsed into his transgressive body and seductive embrace. ${ }^{20}$ The incursion of the monstrous vampire brings to the surface issues of Mina's social indoctrination into proper femininity while simultaneously cloaking them as "just" a Gothic romance.

In conjunction with this monstrous threat, Stoker introduces a cultural physician and detective who can diagnose and destroy it. As doctor, scientist, and psychiatrist, Van Helsing has all the forms of knowledge at his disposal to read Dracula's secret essence - the body of vampirism - that must be properly named, fully known to the investigators, and successfully removed. Along with vampiric transgression, Van Helsing constantly reads both Lucy and Mina, as well as the men in the text, through the normative sciences of degeneration and sexology. Suspecting vampirism from the start, Van Helsing depends on a Gramscian form of common sense that combines knowledge of degeneration and science with that of oldworld folklore to make credible what the "nineteenth century up-to-date with a vengeance" (35; ch. 3) characters will not admit as a possibility. Van Helsing's invincible intellect is 
so impressive because he, like Cesare Lombroso and Max Nordau, can draw connections between science and other discourses to construct a way of knowing that meets the needs of this common sense. ${ }^{21}$

The German ex-patriot Max Nordau explores the ever-widening circle of degeneration in his wildly popular study Degeneration, published in English in 1895, just two years before the publication of Dracula. Following his teacher and mentor Lombroso, Nordau argues that not only the modernized European lifestyle of trains and pollution but also art and literature can adversely affect an increasingly enervated bourgeoisie. Nordau seeks to identify and vilify this degenerate element in European society: "Such is the treatment of the disease of the age which I hold to be efficacious: Characterization of the leading degenerates as mentally diseased; unmasking and stigmatizing of their imitators as enemies to society; cautioning the public against the lies of these parasites" (560). The highly charismatic yet egoistic artists of decadent literature, including Zola, Nietzsche, and Wilde, reflect their pathology in their writing. Nordau's task in his vast tome of criticism is to identify the artistic stigmata of degeneration in these otherwise appealing and seductive figures - the fate of European nations depends on proper detection and destruction of these threatening, enervating degenerates.

Through his invocation of science, Nordau is able to gain up-to-date credibility for his particularly suspicious way of looking at the world, but we can see his work, and by extension Van Helsing's as well, as the production of scapegoats for a society that saw itself as under attack and in decline. In his study The Scapegoat, René Girard establishes a way of reading the psychosocial context of "the very specific imagination of people who crave violence":

The text we are reading has its roots in a real persecution described from the perspective of the persecutors. The perspective is inevitably deceptive since the persecutors are convinced that their violence is justified; they consider themselves judges, and therefore they must have guilty victims, yet their perspective is to some degree reliable, for the certainty of being right encourages them to hide nothing of their massacres. (6)

Told at moments of massive crisis, like the plague or other threats to an entire community, scapegoat stories place some moral crime within a socially marginalized person or body of people and then seek to purify the community by exiling or killing these "guilty" outsiders:

[T] he victims are chosen not for the crimes they are accused of but for the victim's signs that they bear, for everything that suggests their guilty relationship with the crisis; ... the import of the operation is to lay the responsibility for the crisis on the victims and to exert an influence on it by destroying these victims or at least banishing them from the community they "pollute." (24)

With these scapegoats destroyed, the community itself is cleansed, ensuring that normality will return without further suffering.

These crucial signs of guilt, of crimes against the community, can be summed up in one word: monstrosity. Yet, paradoxically, the terror of monstrosity results not from its completely alien nature but from disturbing similarities to the community itself: "[Monsters] always consist of a combination of elements borrowed from various existing forms and brought together in the monster, which then claim an independent identity." Monsters result from the "dizzying" effects of disintegrating perception in times of crisis and also attempts 
to regain control of it: "A monster is an unstable hallucination that, in retrospect, crystallizes into stable forms, owing to the fact that it is remembered in a world that has regained stability" (Girard 33). The traits that are chosen to create a useful monster, then, are always ideologically driven - the physical signs of monstrosity that announce its difference are those of the moral signs of normality that demand reinstantiation: "Moral monstrosity, by contrast, actualizes the tendency of all persecutors to project the monstrous results of some calamity or public or private misfortune onto some poor unfortunate who, by being infirm or a foreigner, suggests a certain affinity to the monstrous" (34). Rather than being an external, alien contaminant, monsters are often instead insiders comprised of "Physical and moral monstrosity ... heaped together in myths that justify the persecution" (35).

Exploring this connection of the familiar and the foreign, Kathleen Spencer analyzes both Lucy and the Count as the scapegoat figures of the novel. Following Girard, she explains that "what all sacrificial victims have in common is that they must recognizably belong to the community, but must at the same time be somehow marginal, incapable of fully participating in the social bond" (209). Besides reading Lucy's letters to Mina, Van Helsing reads her body as well, a part of his quest to identify the "true nature" of the vampire. Lucy's condition, the newest example of Dracula's circle of corruption, must speak the simple truth of vampirism with every word and motion; the quest of the novel is to recognize these stigmata and exterminate the threat. Through her excessive emotion and sexual desire, Lucy is positioned outside Victorian normativity and thus draws the vampire to her. Lucy's vampiric seduction metaphorically represents all manifestations of her excess, intensifying her subversive desires for her other suitors and Mina into the encroaching threat of the vampire. Like Lombroso, Van Helsing reads the signs of Lucy's impending degeneration by the signs of her body. Her "ghastly, chalkily pale" face (118; ch. 10), "the pale gums drawn back from the teeth, which thus looked positively longer and sharper than usual" (150; ch. 12), and most importantly the fang marks on her neck all serve as the stigmata of her vampirism. Through his "common sense" identification of the vampire, Van Helsing dooms Lucy but simultaneously idealizes her in order to naturalize the social order. He must convince the "little band of men" to sacrifice Lucy in order to cleanse the male community: "In death Lucy becomes again the angel she had been in life; she also becomes a bond between three rivals, where in life she could only have been a source of division" (Spencer 212). Monster Lucy with her fangs and voluptuous titillation must be staked back into passivity not just to save her soul but to salvage the homosocial community her sexuality brought into crisis. ${ }^{22}$

Difference in this "othering" ritual of border identification slips into similarity, however, ensuring the scapegoat will in fact continue to haunt the community its expulsion is supposed to cleanse. The allure of the vampire, the titillating attraction/repulsion all the characters feel, is not a foreign contamination but instead is based within each of the characters in the novel. Each man and woman has the propensity to fatally slip into the vampiric. Girard notes that not only foreigners and those obviously outside can become scapegoats - so too can the "marginal insider" (18): "Extreme characteristics ultimately attract collective destruction at some time or other, extremes not just of wealth or poverty, but also of success and failure, beauty and ugliness, vice and virtue, the ability to please and to displease" (19). To be marked as excessively pure, innocent, and virtuous can also put a young woman at risk. Just as Van Helsing must render Lucy as completely demonic, he must present Mina as perfectly good: "She is one of God's women fashioned by His own hand to show us men and other women that there is a heaven where we can enter, and that its light can be here on earth" 
(185; ch. 14). By reading Mina's purity as stringently as he reads degeneracy in Lucy and the Count, Van Helsing attempts to recuperate the possible disruption posed by her "man's brain" and "woman's heart" (232; ch. 18). But Mina herself, through a series of journal entries that foreground her propriety, reveals her own "certain affinity with the monstrous" (Girard 34), the vampiric affinities that position her as another potential scapegoat within the text of Dracula.

Stoker's novel represents issues of discipline not just through Van Helsing's knowing gaze but also through Mina's character construction in reaction to that gaze. Lucy's transformation and destruction function as cautionary examples for Mina. She learns not only that vampires and transgression must be brutally brought into line but also what can happen to anyone outside the Victorian codes of normalcy. Stoker's vampire story, especially its lurid description of Lucy's staking, shows what can happen to a woman who transgresses strict gender codes, but just as important is the way Mina attempts to re-constitute her normality in reaction to this discipline. ${ }^{23}$ Mina Harker, the proper woman with the man's intelligence, is actually the most dangerous nascent vampire in the text because what makes her an exceptionally proper woman is also what links her to the vampire. She works diligently, in a Victorian society that overvalues work, to be helpful to her husband; she works tirelessly to inculcate propriety to her students and her friend as an assistant schoolmistress; she works efficiently to transcribe and collate the knowledge by which Dracula will be destroyed. Yet her virtuoso performance of proper femininity now draws suspicion upon her, and no matter how hard she tries to prove herself proper, she can never be proper enough. Eliza Lynn Linton leaves open the possibility for "good" women to be "quiet workers who content themselves with doing good work of a non-glaring kind - work that merely advances our knowledge in certain directions, and that raises all with whom it is associated... These are the women who keep the world of feminine activities pure and sweet" (462). While Linton here claims that the right kind of female intellectual labor can be both feminine and useful, we have to wonder exactly how such a thing would be possible — how can Mina be an active "non-glaring" woman without becoming Grand's "cow-woman"? How can she prove both her ability and her propriety when all signs of activity are read as proof of deviance? This paradox of femininity makes Mina a potential threat, especially when emphasized by the presence of the vampire.

Stoker's text draws strong affinities between Mina and Count Dracula, either through triangulation across an attractive female body or through direct contact, but these moments of vampiric affinity are often self-consciously obscured by Mina's overly fastidious selfpresentation as proper lady. On the night of Lucy's initial vamping, Mina sees her friend in the cemetery at Whitby: "it seemed to me as though something dark stood behind the seat where the white figure shone, and bent over it. What it was, whether man or beast, I could not tell" (90; ch. 8). For Lucy, this intercourse with Dracula is figured as an exaggerated fulfillment of her earlier sexual curiosity. Longing to marry three men at once, willing to kiss a rejected suitor, perhaps even feeling desire for her passionate friend, Lucy here enjoys a displaced sexuality as both monstrous and fulfilling. At the same time, Mina's thoughts are most concerned with issues of propriety. Recording her own naïveté in her journalistic account of the night, Mina attempts to guess Lucy's destination from her (lack of) clothing. Worrying about Lucy's reputation as well as her own, she shows herself daubing mud on her feet to avoid attention. While such details may seem proof of her own inherently proper and even prudish character, these overtly, even obtrusively, proper visions of her 
own conduct demonstrate that Mina has internalized her social discipline as her sense of self. ${ }^{24}$ Despite this emphasis on propriety, however, she simultaneously places herself in a markedly vampiric position. As Mina gathers Lucy into her protective embrace, she fears that she is the one who has pricked her dear friend: "I fastened the shawl at her throat with a big safety-pin; but I must have been clumsy in my anxiety and pinched or pricked her with it, for by-and-by, when her breathing became quieter, she put her hand to her throat again and moaned" (91). While the overtones of this scene are decidedly heterosexual, it begins to shape a connection between Mina and Dracula that becomes more pronounced throughout the novel.

Mina's connection with the Count is accentuated in another textual moment when she and Harker discover the vampire in the heart of London:

I was looking at a very beautiful girl, in a big cart-wheel hat, sitting in a victoria outside Giuliano's when I felt Jonathan clutch my arm so tight that he hurt me, and he said under his breath: "My God!" I am always anxious about Jonathan, for I fear that some nervous fit may upset him again; so I turned to him quickly, and asked him what it was that disturbed him.

He was very pale, and his eyes seemed bulging out as, half in terror and half in amazement, he gazed at a tall, thin man, with a beaky nose and black moustache and pointed beard, who was also observing the pretty girl. (168-69; ch. 13)

While the text emphasizes the moment's gender disruption (Jonathan's passivity as a return of his brain fever, Mina in the unusual role of protector), it also connects Mina directly with the vampire - she and Dracula are looking at precisely the same object of beauty. While the Count is clearly marked as predatory, Mina's own benign, admiring gaze becomes uncanny. In the un-pathologizing social climate of the earlier nineteenth century, Mina's scopophilic admiration would not fall under scrutiny; in a Nordau-esque society committed to unearthing and destroying hidden morbidity and sexual deviance, however, her benign gaze draws suspicion. Mina's moment of quiet enjoyment, unself-consciously viewing a woman as an object of beauty, becomes marked as threatening with the Count's unexpected entrance.

Mina's ultimate moment of New Woman frustration comes on the heels of her most substantial contribution to tracking the vampire. As she types, collates, and distributes the journals, letters, and other bits of writing that make up the text of Dracula, she becomes the lady journalist she has longed to be all along. Her abilities as a lady journalist, and the foresight of typing up Harker's journal, lead to Van Helsing's praise of her man's brain and woman's heart. Yet the New Woman propensities she reveals here lead Van Helsing to cut her out of the loop of knowledge and vampire hunting:

\footnotetext{
Ah, that wonderful Madam Mina! She has man's brain - a brain that a man should have were he much gifted - and woman's heart. ... Friend John, up to now fortune has made that woman of help to us; after to-night she must not have to do with this so terrible affair. It is not good that she run a risk so great. We men are determined - nay, are we not pledged? - to destroy this monster; but it is no part for a woman. Even if she be not harmed, her heart may fail her in so much and so many horrors; and hereafter she may suffer - both in waking, from her nerves, and in sleep, from her dreams. And, besides, she is a young woman and not so long married; there may be other things to think of some time, if not now. (232; ch. 18)
} 
Seward "agreed heartily" (232) with this decision, as do all the men, and it is not hard to see why. Against the active mind and helpful typewriter of this proper "New Woman," Van Helsing raises the specter of motherhood. Although Mina has mentioned motherhood only once (when Holmwood is sobbing on her shoulder for poor dead Lucy), the threat of failing to be a good mother is already coercive enough to force her back into domestic passivity. After she plays secretary one last time as Van Helsing dictates his lesson on vampirism, Mina is effectively ostracized from the group:

\footnotetext{
"And now for you, Madam Mina, this night is the end until all be well. You are too precious to us to have such risk. When we part to-night, you no more must question. We shall tell you all in good time. We are men, and are able to bear; but you must be our star and our hope, and we shall act all the more free that you are not in the danger, such as we are."
}

Acting under the aegis of paternalistic concern, Van Helsing and the other men reduce the proper New Woman to the level of inspiration, future mother, and helpless child - they have effectively reduced her to a cow-woman in waiting, the perfect mother of the children that are to be. Unwilling to break out in open rebellion, Mina chafes under this chivalric protection: "though it was a bitter pill for me to swallow, I could say nothing, save to accept their chivalrous care of me" (239; ch. 18).

As the men arm themselves and march off to Carfax Abbey, Mina has no choice but to retire to her bedroom. While she casts her discontent as care for the men she loves, her frustration at being cut off from knowledge is obvious as she notes her "devouring anxiety" (254; ch. 19). In her snappish journal entry the next morning, she lashes out at Jonathan for withholding information, peevishly recalling his vampiric arousal in Castle Dracula by writing, "But to think that he keeps anything from me!... Well, some day Jonathan will tell me all; and lest it should ever be that he should think for a moment that I kept anything from him, I still keep my journal as usual" (254). And of course what she records is her own initial vamping, though she does not recognize it as such. It is no mistake that this is the moment when Dracula comes to her. Cut off from the New Woman knowledge she craves, prevented from helping to avenge her passionate friend, overcome by emotion, Mina calls the vampire to her just as the sexually provocative Lucy had done earlier in the text. ${ }^{25}$ Forced into passivity by the codes of propriety she has attempted to rewrite to allow for her own activity, she now indeed gives in to paternalistic dictates, but in a way that Van Helsing and Jonathan Harker could never have predicted. As the vampire materializes in front of her, "some leaden lethargy seemed to chain my limbs and even my will. I lay still and endured; that was all" (255). Even as the men congratulate themselves for protecting Mina, she has her first direct experience of real transgression, rendering their ideal of passive femininity completely uncanny.

The vampiric sex scene between Mina and Dracula acts as a manifestation of the unfixing of gender boundaries, a making literal of the indeterminacy of the paradox of femininity. A middle-class girl who wanted to be helpful to her husband and have job skills of her own, Mina tried to combine active work and Victorian propriety; a young woman and teacher who has lost her friend and protégée to the most terrible of deaths, Mina only wanted to have an intimate relationship that she sees as completely natural. Yet under the suspicious gaze of Van Helsing and the cultural imperatives of degeneration theory, all her attempts 
at self-fashioning have become embodied in the monstrous form of the vampire. Seward describes the scene:

On the bed beside the window lay Jonathan Harker, his face flushed, and breathing heavily as though in a stupor. Kneeling on the near edge of the bed facing outwards was the white-clad figure of his wife. By her side stood a tall, thin man, clad in black. His face was turned from us, but the instant we saw it we all recognized the Count - in every way, even to the scar on his forehead. With his left hand he held both Mrs Harker's hands, keeping them away with her arms at full tension; his right hand gripped her by the back of the neck, forcing her face down on his bosom. (279; ch. 21)

This displaced vampire scene shows us not penetration of the neck as we expect, but rather Mina sucking on the breast of the Count, creating further gender confusion. Christopher Craft has identified the "vampire mouth" as "the central and recurring image of the novel" (109), an unstable sign of transgressive sexuality, signaling misplaced appetite, penetration that is not strictly penile. Blood sucking and generative, it is the site of complete confusion, invoking all gender codes simultaneously. Whereas the men may have been somewhat ready to finally witness this vampire mouth at work, what they witness instead is even more confusing the all-too-human mouth of their "star and hope." Like Harker's desperate comparison of the "devils of the Pit" to his completely pure and innocent Mina, this forced realization of the affinities between the vampire mouth and the human make the moment even more monstrous. It is the presence of the familiar within the monstrous, the misplaced quality of this floating signifier of anxiety, that makes it so uncanny. Nor can they read this scene only as sadistic rape - the key to recognizing the appeal of the vampire rests in exactly the myth's own terms: the vampire is about seduction and intent, not force and rape. Mina is actively participating, and reluctantly admits her own complicity: "strangely enough, I did not want to hinder him" $\left(284\right.$, ch. 21) ${ }^{26}$ This primal image defies all familiar categories; it is a vertiginous moment that requires yet frustrates definition. It represents a moment of ideological indeterminacy that must be recuperated but cannot. Tellingly, both Seward and Mina recount the scene, vainly attempting to bring it back into familiar categories. Yet indeterminacy, and Mina's vampiric affinity with the Count, continues to circulate throughout the rest of the novel.

In the disorienting cultural milieu of the New Woman and the newly pathologized passionate friendship, Mina marks the point where the seemingly familiar model of womanhood becomes estranged as other. Although Mina has internalized a heterosexual performance as the only acceptable space within her society, the incursion of the vampire radically calls any straightforward understanding of femininity into question. Despite his uncanny effects, Count Dracula represents a threat that is paradoxically posed as stabilizing. While Nordau is deeply afraid of the contaminating force of the charismatic and desirable degenerates, his task is to identify and destroy their alien threat. ${ }^{27}$ Van Helsing's pursuit of the vampire, and especially his diagnosis of the Count as "child-brain" (337; ch. 25), functions in a similar way, safely determining the contaminating presence and removing it forever, making the body politic of England clean once more for "the children that are to be" (182; ch. 14). The threat of Lucy and Mina is much more problematic for Van Helsing and the ideology he represents. While he can stake Lucy into his idea of proper female conduct, and he can tell Seward "Madame Mina, our poor, dear Madame Mina, is changing" (319; ch. 24) to mark her as contaminated, the real threat of vampiric Mina is that she is always already a bit vampiric to start with. Mina's "devouring anxiety," and its intensification into 
the "vampire mouth," serves as the text's essential disruption, sparking endless discourse and reinscription of the vampire but also ensuring that this threat will continue to circulate past the end of the text.

\section{Conclusion: Mina's Vampiric Affinities}

MINA HERSELF never fully embraces the transgressive desire of the vampire. Through her insistent self-fashioning in the same codes Van Helsing and the Englishmen value, she constantly attempts to downplay her affinity with the Count. Yet her attempts to assist the men and to purify herself continue to mark her connection to the vampire. In her role as maternal comforter, she not only consoles Harker and Arthur Holmwood but also feels compassion for Dracula: "I suppose one ought to pity anything as hunted as is the Count" (226; ch. 17). Reacting against the men's hatred of the vampire, she makes her connection to him explicit:

\footnotetext{
"That poor soul who has wrought all this misery is the saddest case of all. [...] You must be pitiful to him too, though it may not hold your hands from his destruction," [she says ...] "Just think, my dear - I have been thinking all this long, long day of it - that ... perhaps ... some day ... I too may need such pity." (305; ch. 23)
}

Most telling is her desire to render herself dead. By instructing the men to read the death rite, she gives herself over to their patriarchal control, wishing to become "real dead" like Lucy. Anne Cranny-Francis reads this request as the ultimate proof of Mina's complicity with her own oppression: "In her acceptance of patriarchal ideology Mina asks that, if she transgresses patriarchal norms by becoming sexually assertive, the men should return her to normality - rendering her sexually passive, submissive, receptive" (72). Yet such passive "normality" is only possible through another aggressive act of self-fashioning - we must ask who else wanders the earth despite being dead, who else is a threat, who else do the men seek to disavow via a scapegoating ritual. Mina here renders herself un-dead even more assuredly than her growing fangs mark her as such.

As Van Helsing and Mina draw close to Castle Dracula during the novel's adventure-story finale, Mina is forced to recognize her growing vampirism. When the three vampiric women appear at their campsite, Van Helsing turns to mystical defenses. Mina, however, feels little fear: "Fear for $m e$ ! Why fear for me? None safer in all the world from them than I am" (363; ch. 27). The vampire women also recognize this affinity, calling to her as a sister. Ultimately Mina refuses this invitation, rejecting vampiric desire even as the unclean mark on her forehead clears with Dracula's death. But despite this seeming rejection, the text of Dracula keeps the radical potential of the vampire in play. If read according to a male-dominant, teleological plotline of adventure and simple expulsion, Dracula functions as a successful scapegoat narrative that safely and efficiently identifies deviant insiders and monstrous outsiders in order to cleanse the men's society and remove the mark of sin from Mina's forehead. Things might look different, however, if we question exactly how successful Stoker's scapegoating strategy really is - or, better, how a scapegoat function, especially in Gothic literature, necessarily raises more anxieties than its "predictable" ending can possibly control.

David Punter suggests that Gothic fiction is not primarily about the refixing of troubled boundaries but rather about the production of "a 'negative psychology,' access to the denied 
hopes and aspirations of a culture... . Rather than jumping straight from an existent situation to a projection of its opposite, Gothic takes us on a tour through the labyrinthine corridors of repression, gives us glimpses of the skeletons of dead desires and makes them move again" (409). We cannot see a Gothic narrative like Dracula as a straightforward, teleological production of normative femininity - instead, the various temptations, attractions, threats, prohibitions, and punishments all work together, and in excess, to form a new picture of normative femininity that is produced precisely by trying to somehow move outside it. An excellent example is Mina's passionate friendship with Lucy. According to Punter, "Gothic writers work - consciously or unconsciously - on the fringe of the acceptable, for it is on this borderland that fear resides. In the best works, the two sides of the border are grafted on to each other... displaying on one side the contours of reality, the detail and structure of everyday life, on the other the shadowy realm of myth, the lineaments of the unacceptable" (409-10). In Mina's friendship we see a "Gothicized" boundary of the acceptable - the friendship itself is equally accepted, socially encouraged, and pathologized. The shadowy and only dimly understood threat of lesbian desire emerges to disrupt the asexual, idealized friendship of two women who share a house without a male chaperon. Dracula himself emerges as the literalization of this paradox, not because Mina and Lucy are lesbians but as a safely monstrous face for a new fear, a "monster of prohibition" to demarcate and make monstrous a new social transgression. Following Jeffrey Jerome Cohen,

[T] he monster of prohibition polices the borders of the possible, interdicting through its grotesque body some behaviors and actions, envaluing others. . . . Every monster is in this way a double narrative, two living stories: one that describes how the monster came to be and another, its testimony, detailing what cultural use the monster serves. The monster of prohibition exists to demarcate the bonds that hold together that system of relations we call culture, to call horrid attention to the borders that cannot - must not - be crossed. (13)

As we see, and as Mina herself sees, the penalty for giving in to this new desire is not only to become newly monstrous oneself but to be hunted, attacked, and brought violently back into normativity through any means necessary. Dracula's seductive embrace, and the fangs his kiss results in, mark both the Count and Lucy as the scapegoats necessary to purify the community of men, and of women, of potential threats to the dominant social system.

Monsters are not only prohibitive, they are also infinitely attractive. By representing the promise of sexuality forbidden to Lucy by her mother and the marriage market, Dracula presents an attractive if taboo model of sexual freedom. But as we have seen, he is also attractive to Mina not because of sex per se but because of Mina's own vexed relationship to knowledge. Due to Van Helsing's repeated efforts to infantilize her through paternalistic injunction, knowledge itself has become taboo for Mina: "tabooed objects are those to which we summon up not a simple emotional reaction but a dialectical one in which the mind oscillates between attraction and repulsion, worship and condemnation" (Punter 410). In his attempts to protect Mina and mystify his own "common sense" knowledge, Van Helsing has rendered knowledge itself taboo for Mina. And even more paradoxically, proper femininity itself has become unclear - all she wants is to help her husband, to solve the mystery of what happened to her friend, and to feel that her work as lady journalist is useful. Yet in the context of Van Helsing's suspicious gaze and the conservative press's pillorying of the New Woman as the great threat to society, Mina's self image has become a site of 
“emotional ambivalence" (Punter 410), not unlike Lucy's taste for extra-marital sex. Now both a site of tabooed knowledge as well as sexual potential, Dracula has become even more attractive to his next victim: "This corporal fluidity, this simultaneity of anxiety and desire, ensures that the monster will always dangerously entice" (Cohen 19). Comprised of all Van Helsing's worries and prohibitions, all of Lucy's longings and desires, and all of Mina's musings, ambitions, and "devouring anxiety," Dracula has become the perfect monster of the Victorian fin de siècle.

There is a fundamental gap between the cultural work a monster performs and the message the narrative form of the Gothic novel allows. By creating the monster as a monster of prohibition and often literalizing the threat that the human who transgresses will indeed be treated as a monster as well, cultural imperatives of normativity are not only enforced, they are naturalized as the only viable way to live - anything else becomes unthinkable. Whereas the Gothic narrative demands closure, it also requires that the closure fail to contain the transgressions the story has put into play. The monster of prohibition is also always the monster of attraction, a figure with whom we identify, a site of attractive/repulsive desire. The text is compelling precisely because the formation of monsters, and thus the ideological definition of what counts as human, is a never-ending performative process. ${ }^{28}$ Encouraged both consciously and subconsciously to enact the privileged scripts of normative identity as the only thinkable mode of being, the subject must always exist precariously close to falling into the realm of the abject, or, in more Gothic terms, the monstrous. Gothic novels gain their power by investigating this ideological paradox - that the natural, the only thinkable way of existing, needs the monstrous to gain credibility and to give it form. But as Fred Botting reveals, playing with monsters always subverts the same boundaries it seeks to uphold:

Constructed as a figure of transgression, an other that marks out the boundaries of discourse, the monster also begins to disclose internal contradictions within discursive frameworks.... Monsters are thus produced by and also reveal inherent instabilities: refusing to remain in a fixed space of exclusion or to be contained at the margins of any one position, they pose a permanently shifting challenge and produce the possibility of significant transformations. The excess that is constructed by various positions in order to define their limits also works upon and within them, inhabiting and undermining the fixity of their boundaries. (26-27)

Because monsters are always the constitutive outside of normativity, the scapegoats constructed of society's devouring anxieties, they can never safely be tucked away. Revenants always return because the "human" is always a category under reconstruction, and the outside must be constantly re-articulated so the inside can imagine itself as stable, viable, natural.

Mina Harker represents exactly this paradox as she attempts to survive Dracula's invasion and seduction - and Van Helsing's scapegoat ritual of community cleansing. Through his sciences of degeneration and sexology, Van Helsing proves Dracula and Lucy are monsters of prohibition, legitimizing his violence to reaffirm his own ideology as the natural one. And through the mythic quality of Dracula's destruction, this scapegoat ritual seems concluded: once Mina's scar clears, normativity is reaffirmed. The journal entry that concludes the novel, written by Jonathan Harker, seeks to emphasize this same conclusion. In this final note, Harker reports that seven years later all is well. The adventurers have returned to Transylvania as tourists to go "over the old ground" again ( 373 ; ch. 27$)$. The whole scene seems rather antiseptic - the old threat of danger is clean and pure, a safe place for the 
tourists to revisit. He and Mina have a son, whom they have named for the dead Quincey Morris. This child, and Seward and Holmwood's new marriages, assure propriety; Mina's presence as silent mother attests to the reinscription of homosociality and patriarchy. And the fact that they have no real "proof" for the contents of the journal - "nothing but a mass of type-writing" (374) - makes the story seem too unbelievable to have happened. Normativity seems restored without a hitch, symbolized by silent, maternal Mina holding her child.

Yet things are not really this tidy. Harker's note reveals that Dracula's power is still manifest, that the societal anxieties which he represents still circulate. The new tourism finds an indelible reminder of vampiric threat - Castle Dracula has not changed a bit. Most disturbing, though, is the very presence of Mina's typewriting. Not only does the evidence still exist despite Harker's denial, it retains the form that gives Mina her power and identity. The mark of the New Woman is still discernible, even if Harker refuses to acknowledge it. Harker would make of Mina and the entire story what Van Helsing once called her, a "good lesson for the children that are to be" (182; ch. 14). The final words of the novel, from Van Helsing of course, complete Mina's recuperation as a model in a children's tale: "This boy will some day know what a brave a gallant woman his mother is. Already he knows her sweetness and loving care; later on he will understand how some men so loved her, that they did dare much for her sake" (374; ch. 27). Unable to combat Harker or Van Helsing within Harker's note, silent Mina seems indeed to be contained inside a standard Victorian position. The apparent stability of this final note, however, is framed by the opening note of the novel. This note asks us to believe the story as factual and unbiased:

\footnotetext{
How these papers have been placed in sequence will be made clear in the writing of them. All needless matters have been eliminated, so that a history almost at variance with the possibilities of the latterday belief may stand forth as simple fact. There is throughout no statement of past events wherein memory may err, for all the records chosen are exactly contemporary, given from the standpoints and within the range of knowledge of those who made them. $(\mathrm{xxx})$
}

This note, stressing the accuracy of the written record Mina has compiled into the text of Dracula, warns against "latter-day belief" that might try to dismiss the valuable knowledge contained within. Like Mina's journal entry after her initial vamping, it stresses that everything is present in the text, even if it is unseemly or problematic for Van Helsing's normalizing gaze or Harker's stabilizing conclusion. No matter how the men try to make Dracula simply prohibition, his attraction remains and overwhelms this final image of tooneat propriety.

This paradox of monstrosity, then, is also the paradox of femininity. The idealized proper lady - Harker's chivalric ideal, Van Helsing's "star and hope," Eliza Lynn Linton's "nonglaring worker" - is just as much an impossible being as the vampire-as-monster. Just as Dracula cannot exist because his monstrosity is constituted in too pure a form, neither can Minaas-"stereotypically 'good' little Victorian Miss" exist (Ledger, "The New Woman" 30) no woman could ever possibly measure up to the stereotype. Failure is assured. Unless Mina can pass as Van Helsing's "star and hope," unless she can be a self-reflective version of Linton's "cow-woman" and play that role perfectly, she can be read as monster and justifiably exterminated. Thus we get no final comment from Mina on her married life, whether she is indeed truly the happy wife and mother Harker makes her out to be. Indeed, Mina isn't even the one holding her child as her maternal bliss is described - Van Helsing is the one who has 
“our boy on his knees" (374; ch. 27). We must rely on Harker for the image of wedded and maternal bliss, but Mina's journal has amply exposed the danger of taking Harker at his word. Thus we have reached an impasse - Van Helsing's suspicious gaze, Mina's internalization of that gaze as the true limit of the thinkable (for to think otherwise is to reveal monstrosity and to court destruction), but also Dracula's infinite attractiveness. Mina's story - a full record of her New Woman affinities, her problematic friendship with Lucy, the desirability of a monster, and her overacted propriety - will be passed on to her child. Mina has indeed become a "lesson for the children that are to be." Yet if we take seriously the complexity of this ambivalent text, with all its devouring anxiety and vampiric affinities in place, what her lessons will teach may not be as secure as Van Helsing might like to think.

\section{Southern Vermont College and University of Illinois at Urbana-Champaign}

\section{NOTES}

We would like to thank David A. H. Hirsch, Julia Saville, Gretchen Soderlund, and Mary Ann Giorgio for reading, proofreading, and critiquing various drafts of this article. The article has benefited from their valuable and rigorous insights and suggestions, as we have benefited from the understanding and support of Sarah Doig, Lori DuBois, Eric Fisher, and Jeff Harshbarger during the many years of its composition.

1. Poovey and Armstrong both have argued persuasively and influentially that the image of the "proper lady" that was circulated in conduct books and domestic fiction shaped the way women viewed themselves during the late eighteenth and nineteenth centuries.

2. Similarly, Cranny-Francis argues that Dracula "reproduces fictionally the contradictions within bourgeois ideology and then resolves or neutralizes them" (64). Whereas vampiric Lucy represents a threat to the male order, the passive, feminine Mina functions as a kind of patriarchal patsy: "the attributes given to Mina which suggest power, ability, assertiveness are progressively appropriated by the men around her. Her intelligence is seen as a masculine attribute to which she has somehow gained access - it is not naturally available to women; while the potential threat of the intelligent woman is averted by a display of male physical, intellectual and sexual dominance and of female submission. There is nothing in the text to suggest any kind of belief in the "New Woman"' (72).

Kline goes even further, completely rejecting any complexity in Mina's character: "Mina is not really dual-faceted at all. She is an age-old fantasy figure, an archetype, a sentimental male chauvinist's dream in every single aspect of her character" (130).

3. According to Mangum, "After the passage of the Married Women's Property Acts of 1882 and 1891 guaranteed women possession of their earned income, middle-class women more confidently moved into the workforce as teachers, nurses, midwives, clerks, writers, and journalists" (Married 2). Similar advances were made in education for women, as Ledger notes: "During the 1870s, 1880s and 1890s many new secondary schools for girls were founded, all committed to high academic standards, examinations and trained teachers. By 1898, 80,000 girls over the age of twelve were attending secondary schools" (New Woman 17).

4. For discussions of Sarah Grand's novels and politics, see Mangum's Married, Middlebrow, and Militant: Sarah Grand and the New Woman Novel, Ledger's discussion of The Heavenly Twins in The New Woman (111-18), and Senf's introduction to The Heavenly Twins.

5. In his highly influential article "Kiss Me with Those Red Lips," Craft reveals Harker's passivity as a threat to Victorian gender norms: "Immobilized by the competing imperatives of 'wicked desire' and 'deadly fear,' Harker awaits an erotic fulfillment that entails both the dissolution of the boundaries of the self and the thorough subversion of conventional Victorian gender codes, which constrained 
the mobility of sexual desire and varieties of genital behavior by according to the more active male the right and responsibility of vigorous appetite, while requiring the more passive female to 'suffer and be still"' (108).

6. Fleissner offers a compelling answer to the question of Mina's labor by placing her in the developing historical discourse of nineteenth-century clerical work for women. Fleissner reveals that from the 1870s up to World War I, women gained increasing economic and social acceptance as secretaries: "women's clerical work was not simply a historical scandal to which citizens responded with disavowal and alarm. In the period during which Dracula was composed, rather, typewriting was increasingly becoming viewed as part of an acceptable narrative of a middle-class woman's life. The question, then, would be one of how secretarial work gets figured as a position from which a woman can go home again - to become the idealized mother we see Mina become on that final page" (419). While Fleissner offers an excellent historical discussion of the emergence of the feminization of clerical work, she does not fully comment on how this compelling social narrative competed with the equally powerful narrative of the pathologized New Woman worker. She also downplays Mina's agency as thinker and writer, casting her as simply a stenographer for Van Helsing, Seward, and even Dracula himself. It is crucial to see Mina's work not simply as stenography from male bosses, but also as an ambivalent claim to identity based on her creative work as a journalist and her "devouring anxiety" (Stoker 254; ch. 19) at being cut off from the knowledge she collects.

7. As Wicke notes of other journalistic dialect included in the novel, this emphasis on journalism works to highlight the modern in Dracula: "the point of the article seems as much to be transcribing the loquacious dialect of the zookeeper as adding to anyone's knowledge of the habits of Dracula. The newspaper page serves as a theater for the staging of class differences when its 'standard' written English can erupt with the quoted, vigorous orality of lower-class modes of speech" (475).

8. The question of Stoker's Dracula and its relation to the New Woman has received extensive critical attention. According to Ledger, Stoker, like many male writers on the Woman Question, is part of the conservative backlash, presenting the New Women as "daughters of decadence" whose sexuality is a "degenerate aberration which must be extinguished" (New Woman 100). Whereas Ledger focuses solely on Lucy and the three "weird sisters" as New Women, Johnson argues that Mina's relationship to work, as well as Lucy's relationship to sex, constitute sufficient grounds for considering both as New Women. In perhaps the most influential article on the New Woman in Dracula, Senf acknowledges that Mina shares some of the characteristics of New Womanhood but stresses her commitment to traditional womanhood:

[T] he second half [of the novel] centers on a woman who combines the independence and intelligence often associated with the New Woman with traditional femininity - Mina Harker... That she is not a New Woman can be seen in her criticism of the New Woman writers, her choice of profession - the New Woman writers favored such nontraditional professions as medicine, nursing, and business for their heroines - her decision to marry and her subsequent relationship with her husband, her desire to nurture and protect children, and - most clearly - her response to Dracula himself. (45-46)

While we agree with Senf's final analysis that Stoker "tries to show that modern women can combine the best of the traditional and the new when he creates the heroine of Dracula - Mina Harker" (49), we re-examine most of Senf's criteria that distance Mina from the New Woman, focusing instead on how her performance of a problematic gender identity unfixes the boundary of femininity as part of the social milieu of sexology, degeneration, and decadence.

9. Glover links Stoker's later novels to New Woman fiction, but he argues that "Stoker redeployed their tropes and devices, turning them against the women's movement and pressing home sharply revisionist conclusions" (106) that are strongly influenced by the work of Otto Weineger. For Stoker's reworking of Grand's The Heavenly Twins in his novel The Man (1905), see Glover 109-15. 
10. Discussing Harker's journal and Mina's treatment of it, Schaffer writes that "The record of a homosexual affair is dressed in the pastel colors of a heterosexual wedding, to look just like a bridal gift" (405). Schaffer argues that Mina fully accepts her ignorance and Harker's wishes: "his fear and impotence actually evaporate because his wife never blames him for his past - his homosexual secret does not affect his heterosexual relationship.... His real escape from the closet comes when he reveals his secret and it makes no difference" (405). Whether Harker's journal reveals homosexual or monstrous heterosexual desire (or both), we can see that it does indeed make a large difference for Mina as she disseminates her husband's sexual history to all who will read it.

11. In 1811 two mistresses of a girls' boarding school, Miss Marianne Woods and Miss Jane Pirie, sued Dame Helen Cumming Gordon for libel. Dame Gordon's granddaughter, who was born in India, the child of an English man and an Indian woman, told her that these two schoolmistresses "engaged in "improper and criminal conduct"' (Faderman 147). As was customary, the girl shared a bed with Pirie; she told her grandmother that "she had been kept from sleeping by strange goings-on in her bed: In the middle of the night Miss Woods would come into their room, get into bed on Miss Pirie's side, climb on top of Miss Pirie, and shake the bed" (148). Miss Munro, Woods' bed-mate, confirmed the story, and Dame Gordon passed on the information to all parents of the girls at the school. Woods and Pirie claimed that "they had no notion" (147) of the impropriety with which they were charged. In 1819 the House of Lords judged in favor of Woods and Pirie, for they too could not imagine Englishwomen doing what Miss Cumming accused them of: "The judges suggested that Miss Cumming, having been raised in the lascivious East, had no idea of the horror such an accusation would stir in Britain" (148). Lord Justice-Clerk Hope summed up the Lords' reaction to the charges, as well as their investment in an asexual image of English femininity: "No British woman was capable of such action, he said. 'There is not a prostitute so blasted as these women are described by Miss Cumming.' Being certain of the purity of the women whom he knew intimately, he was convinced of the purity of these women of respectable birth. 'I have no more suspicion of the guilt of the pursuers,' he stated, 'than I have of my own wife", (150). See Faderman 147-53 for a full discussion of this court case and the Lords' judgment.

12. A number of critics address the lesbian potential of Le Fanu's vampire story. Faderman considers it an example of late-nineteenth-century "lesbian evil" narratives, holding up a threat to be destroyed. Heller draws out the intimate connections between Carmilla and Laura's growing subjectivity, as well as the ambiguity of the story's ending. Signorotti sees "Carmilla" as a potentially positive lesbian text but argues that Dracula closes down whatever potential Le Fanu's text opens up.

13. Moore offers a powerful critique of Faderman's consideration of same-sex friendships, arguing that Faderman simply asserts female friendships were often accepted rather than analyzing what was at stake in this acceptance. Moore instead asks, "What were the histories, the ideological functions, the effects - and the failures - of these assertions of the harmless and sexless female friendships?" (9) In our consideration of Dracula, rather than simply asserting that Mina and Lucy "are" passionate friends or that they "are" lesbians, we seek to draw out the implications and ideological functions of Mina and Lucy's positioning within this highly complex cultural discourse of passionate friendship. Also, see the special issue of Nineteenth-Century Context (2001), which explores in depth the question of women's friendships and lesbian sexuality; this issue was published after our essay was completed.

14. Ledger notes that because the New Woman and the dandy "both overtly challenged Victorian sexual codes" (New Woman 95), they were lumped together by the conservative press: "Whilst the New Woman was perceived as a direct threat to classic Victorian definitions of femininity, the decadent and the dandy undermined the Victorians' valorisation of a robust, muscular brand of British masculinity deemed to be crucial to the maintenance of the British Empire" (94). Yet as both Ledger and Mangum observe, there were sharp differences between the New Woman and the dandy who "did not perceive themselves to be natural allies" (Ledger, New Woman 94). As Mangum explains, self-consciously political New Woman writers like Sarah Grand tried to distance themselves from the art-for-art's-sake aesthetic associated with Oscar Wilde and other Decadents. Despite their different political platforms, 
however, "critics and consumers tended to collapse the New Woman and the Decadent - whether as actual writers or as fictional types - together as degenerates" ("Style Wars" 49).

15. Krafft-Ebing in Psychopathia Sexualis (1886) and Ellis in Sexual Inversion (1897) construct elaborate taxonomies of difference, drawing on the style of work Lombroso developed in his Criminal Man (1876). Nordau's Degeneration (1895) combines both theories, reading the deviancy of Decadent artists through their artistic works and onto their bodies. While Ellis and later Freud discredit the concept of degeneration, it plays a large part in the criminalization of the homosexual as discussed by Foucault.

For excellent discussions of the cultural politics of degeneration, see Gilman, Arata, Greenslade, and Pick.

16. Noting that, "The New Women of the end of the fin de siècle hadn't the language to describe their erotic relations with other women" (New Woman 131), Ledger suggests that the sexologists, despite their problematic methodology and pronouncements, opened up a discursive space for lesbians to articulate their attraction to women.

17. Mrs. Westenra, Lucy's mother, seems to be in control of her daughter's life. As we learn after Lucy's death, she has left all of her wealth (against her solicitor's wishes) to Arthur Holmwood, leaving Lucy impoverished should she decide not to marry this man. Through inheritance the mother insures her daughter's passage into the heterosexual regime of marriage. See Johnson, "Dual Life" (28-29).

18. While FitzGerald argues that Mina and Lucy's mutual confession offers them a "quasi-sexual pleasure ... something to be enjoyed most in circumstances of physical intimacy" (42), she downplays the potentially homoerotic nature of their friendship.

19. Foucault outlines the social function of confession as a technology of subject formation: "The truth did not reside solely in the subject who, by confessing, would reveal it wholly formed. It was constituted in two stages: present but incomplete, blind to itself, in the one who spoke, it could only reach completion in the one who assimilated and recorded it.... The one who listened was not simply the forgiving master, the judge who condemned or acquitted; he was the master of truth. His was a hermeneutic function" (66-67).

20. Dracula's social significations are nearly as infinite as his infamous polymorphously perverse sexuality. Yet his monstrosity, following Halberstam's theory, is essential to the formulation of the human: "The self-evident nature of the 'human' is constructed in Gothic as the destruction or inscription of the other.... Because of its readability, monstrosity allows us a peek at the construction of otherness out of the raw materials of racial undesirability, class definition, family ties, sexual perversity, and gender instability. The monster, therefore, by embodying what is not human, produces the human as a discursive effect" (45).

21. For a discussion of the ideological function of Gramscian common sense, see Arata (14-19, and his chapter on the Wilde trials).

Like so much else in Dracula, Stoker's invocation of Lombroso and Nordau becomes unexpectedly complex through its relation to Mina. Indeed, it is Mina, not Van Helsing, who names these two theorists of degeneration: "The Count is a criminal and of criminal type. Nordau and Lombroso would so classify him, and qua criminal he is of imperfectly formed mind" (337; ch. 25). Although Mina, and by extension Stoker, seems to invoke Nordau and Lombroso approvingly here, it is essential to note that Mina, with all her New Woman wits about her, names them in order to quietly rebuke Van Helsing by displaying her knowledge of current psychological discourse. Just prior to her statement, Van Helsing has assumed that Seward as a psychologist knows this criminology theory but that pure, good Madame Mina is ignorant, "For crime touch you not - not but once" (336). Yet it is Mina, not Seward, who grasps the significance of Van Helsing's diagnosis of Dracula as a "child-brain" degenerate. More dangerous than the vampire's "child-brain," however, is Mina's "man-brain." Although she hesitates to display her knowledge, demurely requesting that "you will forgive me if I seem egotistical" (338), she cannot resist asserting her intellect. Significantly, even though Van Helsing asks Seward to write up notes about this realization to share with the other men, the chapter ends with Mina 
employing her typewriter to record "all since she brought the MS. to us" (339), including this conversation.

22. Spencer also locates another scapegoat in the novel - Dracula himself. Despite his overstated differences, Dracula is most terrifying because he is uncannily similar to the Englishmen: "he resembles his enemies in several important ways: he is (or once was) human, he is European, he is extremely intelligent and has a most powerful will" (213). When Stoker has Harker say "he would have made a wonderful solicitor" (31; ch. 3$)$, it is more than a joke. The scapegoated Dracula must be killed by the combined efforts of the "little band of men" (373; ch. 27) - only when this particular demon is exorcised can masculinist, heterosexist normativity again pass as unproblematically "natural."

23. Sedgwick has explored this phenomenon in her discussion of homosexual panic in Between Men. As the homosexual becomes an identity rather than a collection of sins or acts (the Foucauldian paradigm), homophobia becomes a way to regulate the many through the persecution of the few via a paradoxical uncertainty of homosexual identity: "Not only must homosexual men be unable to ascertain whether they are to be the objects of 'random' homophobic violence, but no man must be able to ascertain that he is not (that his bonds are not) homosexual. In this way, a relatively small exertion of physical or legal compulsion potentially rules great reaches of behavior and filiation" (88-89). Through constant self-scrutiny and imagined punishment for breaking the normative codes of conduct, societal "blackmailability" (89) renders every person a potential object of discipline.

24. Wicke offers an interesting reading of Mina's self-presentation as she "daubs her feet with mud, so that no reflection of white foot or ankle twinkling in the night can alert any sleepy voyeur who might be looking out a window" (480-81). In the context of Mina's shorthand journal, we as readers are implicated in this voyeurism as the text "presents us subliminally with the image of a Mina thoroughly earth-bound, enmired. The scandal occurs for the reader's eyes alone, so that Mina's earthiness will be underscored even in her hour of intense decorum" (481). In fact Mina presents her self-image of propriety for two voyeurs: us as readers and herself. She is her own primary audience, and she must present herself to her own mind's-eye as exceedingly proper here, as she marks herself as "earth-bound" and imagines herself to penetrate her friend's neck herself. We are supposed to recognize Mina's fastidious propriety, but we also see her connections to both Lucy and Dracula that escape her authorial control. This pattern will continue at key moments throughout the rest of the novel.

25. Johnson implicitly splits up the most troubling aspects of the New Woman, sex and work, between Lucy and Mina: "each woman develops what Van Helsing at one point calls a 'dual life' - a life of conscious and willing conformity to her society and yet also a life of largely subconscious rebellion against it. In the case of each woman, Dracula symbolizes her inner rebelliousness, and its crisis coincides with her commerce with Dracula" (21).

26. Spencer analyzes this key distinction between seduction and rape: "Dracula has drained not only her blood, but also her will to resist. He is, in sexual terms, more seducer than rapist. For a modern reader, this might lessen the crime, but for Victorians seduction would have been infinitely worse. In Victorian theory, it is sexual desire rather than sexual activity that is the true source of danger; and as Mina herself makes clear, she experiences desire under Dracula's attentions" (217).

27. As Söder recognizes, this thought is actually a xenophobic source of comfort for the criminologists and sexologists: "Nordau reassured the bourgeoisie that these instabilities all had one common cause and were curable, since they came from the outside, from the atavistic, infertile, childlike mind of the degenerate" (475).

28. In Bodies that Matter Butler explores the ways our sense of subjectivity is constructed by a process of re-citation of dominant and socially validated codes of normativity: "This exclusionary matrix by which subjects are formed thus requires the simultaneous production of a domain of abject beings, those who are not yet 'subjects,' but who form the constitutive outside to the domain of the 
subject. The abject designates here precisely those 'unlivable' and 'uninhabitable' zones of social life which are nevertheless densely populated by those who do not enjoy the status of the subject, but whose living under the sign of the 'unlivable' is required to circumscribe the domain of the subject" (3).

\section{WORKS CITED}

Arata, Stephen. Fictions of Loss in the Victorian Fin de Siecle. Cambridge: Cambridge UP, 1996.

Armstrong, Nancy. Desire and Domestic Fiction: A Political History of the Novel. Oxford: Oxford UP, 1987.

Botting, Fred. "Reflections of excess: Frankenstein, the French Revolution and monstrosity." Reflections of Revolution: Images of Romanticism. Ed. Alison Yarrington and Kelvin Everest. London: Routledge, 1993. 26-38.

Brennan, Matthew C. "Repression, Knowledge, and Saving Souls: The Role of the 'New Woman' in Stoker's Dracula and Murnau's Nosferatu." Studies in the Humanities 19 (1992): 1-10.

Butler, Judith. Bodies that Matter: On the Discursive Limits of "Sex." New York: Routledge, 1993.

Chauncey, George. "From Sexual Inversion to Homosexuality: Medicine and the Changing Conception of Female Deviance." Salmagundi 58-59 (1982-83): 114-46.

Cohen, Jeffrey Jerome. "Monster Culture (Seven Theses)." Monster Theory: Reading Culture. Ed. Jeffrey Jerome Cohen. Minneapolis: U of Minnesota P, 1996. 3-25.

Craft, Christopher. "Kiss Me with Those Red Lips: Gender Inversion in Bram Stoker's Dracula." Representations 8 (1984): 107-33.

Cranny-Francis, Anne. "Sexual Politics and Political Repression in Bram Stoker's Dracula." NineteenthCentury Suspense: From Poe to Conan Doyle. Ed. Clive Bloom, Brian Docherty, Jane Gibb, and Keith Shand. London: MacMillan, 1988. 64-79.

Cunningham, Gail. The New Woman and the Victorian Novel. New York: Barnes \& Noble, 1978.

Ellis, Havelock. Sexual Inversion. Studies of the Psychology of Sex. 1897. 3rd ed. Vol. 2. Philadelphia: Davis, 1928.

Faderman, Lillian. Surpassing the Love of Men: Romantic Friendship and Love Between Women from the Renaissance to the Present. New York: Morrow, 1981.

FitzGerald, Mary. "Mina's Disclosure: Bram Stoker's Dracula." Gender in Irish Writing. Ed. T. O'Brien Johnson and D. Cairns. Buckingham: Open UP, 1991. 40-45.

Fleissner, Jennifer L. "Dictation Anxiety: The Stenographer's Stake in Dracula." Nineteenth-Century Contexts 22 (2000): 417-55.

Foucault, Michel. The History of Sexuality, Volume 1: An Introduction. Trans. Robert Hurley. New York: Vintage, 1990.

Gilman, Sander L. "Sexology, Psychoanalysis and Degeneration: From a Theory of Race to a Race of Theory." Degeneration: The Dark Side of Progress. New York: Columbia UP, 1985. 72-96.

Girard, René. The Scapegoat. Trans. Yvonne Freccero. Baltimore: Johns Hopkins UP, 1986.

Glover, David. Vampires, Mummies, and Liberals: Bram Stoker and the Politics of Popular Fiction. Durham: Duke UP, 1996.

Grand, Sarah. "The New Aspect of the Woman Question." North American Review 158 (1894): 270-76.

Greenslade, William. Degeneration, Culture and the Novel 1880-1940. Cambridge: Cambridge UP, 1994.

Halberstam, Judith. Skin Shows: Gothic Horror and the Technology of Monsters. Durham: Duke UP, 1995.

Heller, Tamar. "The Vampire in the House: Hysteria, Female Sexuality, and Female Knowledge in Le Fanu's 'Carmilla' (1872)." The New Nineteenth Century: Feminist Readings of Underread Victorian Fiction. Ed. Barbara Leah Harman and Susan Meyer. New York: Garland, 1996. 77-95.

Howes, Marjorie. "The Mediation of the Feminine: Bisexuality, Homoerotic Desire, and Self-Expression in Bram Stoker's Dracula." Texas Studies in Literature and Language 30 (1988): 104-19. 
Jeffreys, Sheila. "Does It Matter If They Did It?" Not a Passing Phase: Reclaiming Lesbians in History 1840-1985. Lesbian History Group. London: Women's Press, 1989. 19-28.

Johnson, Alan P. “'Dual Life': The Status of Women in Stoker's Dracula.” Sexuality and Victorian Literature. Ed. Don Richard Cox. Knoxville: U of Tennessee P, 1984. 20-39.

Jordan, Ellen. "The Christening of the New Woman: May 1894." Victorian Newsletter 63 (Spring 1983): 19-21.

Kline, Salli J. The Degeneration of Women: Bram Stoker's Dracula as Allegorical Criticism of the Fin de Siècle. Rheinbach-Merzbach: CMZ, 1992.

Krafft-Ebing, Richard von. Psychopathia Sexualis. 1886. New York: Putnam, 1965.

Ledger, Sally. The New Woman: Fiction and feminism at the Fin de Siècle. Manchester: Manchester UP, 1997.

_. "The New Woman and the crisis of Victorianism." Cultural Politics at the Fin de Siècle. Ed. Sally Ledger and Scott McCracken. Cambridge: Cambridge UP, 1995. 22-44.

Linton, Eliza Lynn. “The Partisans of the Wild Women.” The Nineteenth Century 31 (1892): 455-64.

Lombroso, Cesare. Criminal Man. (L'uomo delinquente). 1876. Summarized by Gina Lombroso-Ferroro. London: Putnam, 1911.

Mangum, Teresa. Married, Middlebrow, and Militant: Sarah Grand and the New Woman Novel. Ann Arbor: U of Michigan P, 1998.

. "Style Wars of the 1890s: The New Woman and the Decadent." Transforming Genres: New Approaches to British Fiction of the 1890s. Ed. Nikki Lee Manos and Meri-Jane Rochelson. New York: St. Martin's, 1994. 47-66.

Miller, Neil. Out of the Past: Gay and Lesbian History from 1869 to the Present. New York: Vintage, 1995.

Moore, Lisa L. Dangerous Intimacies: Toward a Sapphic History of the British Novel. Durham: Duke UP, 1997.

Nordau, Max. Degeneration. English trans. 1895. New York: Appleton, 1912.

Ouida. "The New Woman." North American Review 158 (1894): 610-19.

Pick, Daniel. Faces of Degeneration: A European Disorder, c. 1848-c. 1918. Cambridge: Cambridge UP, 1989.

Poovey, Mary. The Proper Lady and the Woman Writer: Ideology as Style in the Works of Mary Wollstonecraft, Mary Shelley, and Jane Austen. Chicago: U of Chicago P, 1984.

Punter, David. The Literature of Terror: A History of Gothic Fictions from 1765 to the Present Day. London: Longman, 1980.

Sahli, Nancy. "Smashing: Women's Relationships Before the Fall." Chrysalis 8 (1979): 17-27.

Schaffer, Talia. “'A Wilde Desire Took Me': The Homoerotic History of Dracula.” ELH 61 (1994): 381-425.

Sedgwick, Eve Kosofsky. Between Men: English Literature and Male Homosocial Desire. New York: Columbia UP, 1985.

Senf, Carol A. “'Dracula': Stoker's Response to the New Woman.” Victorian Studies 26 (1982): 33-49.

- "Introduction" to Sarah Grand, The Heavenly Twins. Ann Arbor: U of Michigan P, 1992. vii-xxxvii.

Signorotti, Elizabeth. "Repossessing the Body: Transgressive Desire in 'Carmilla' and Dracula." Criticism 38 (1996): 607-32.

Söder, Hans-Peter. "Disease and Health as Contexts of Modernity: Max Nordau as a Critic of Fin-de-Siècle Modernism." German Studies Review 14 (1991): 473-87.

Spencer, Kathleen. "Purity and Danger: Dracula, the Urban Gothic, and the Late Victorian Degeneracy Crisis.” ELH 59 (1992): 197-225.

Stoker, Bram. Dracula. 1897. Ed. Marjorie Howes. London: Dent, 1993.

Stutfield, Hugh E. M. “Tommyrotics.” Blackwood's 157 (1895): 833-45.

Vicinus, Martha. "Distance and Desire: English Boarding-School Friendships." The Lesbian Issue: Essays from Signs. Ed. Estelle B. Freedman, Barbara C. Gelpi, Susan L. Johnson, and Kathleen M. Weston. Chicago: U of Chicago P, 1985. 43-65.

Wicke, Jennifer. "Vampiric Typewriting: Dracula and Its Media.” ELH 59 (1992): 467-93. 
